\title{
Colony-stimulating Factor-1 Induces Cytoskeletal Reorganization and c-src-dependent Tyrosine Phosphorylation of Selected Cellular Proteins in Rodent Osteoclasts
}

\author{
Karl L. Insogna, ${ }^{\star}$ Malika Sahni, ${ }^{\S}$ Andrew B. Grey, ${ }^{\star}$ Sakae Tanaka, ${ }^{\ddagger \S}$ William C. Horne, ${ }^{\ddagger}$ Lynn Neff, ${ }^{\ddagger \S}$ Maryann Mitnick, ${ }^{\star}$ \\ Joan B. Levy, ${ }^{\ddagger}$ and Roland Baron $\neq \S$ \\ $*$ Department of Medicine, ${ }^{\ddagger}$ Department of Orthopedics and Rehabilitation, and ${ }^{\S}$ Department of Cell Biology, Yale School of Medicine, \\ New Haven, Connecticut 06520-8020
}

\begin{abstract}
Colony-stimulating factor-1 (CSF-1) stimulates motility and cytoplasmic spreading in mature osteoclasts. Therefore, we examined the cellular events and intracellular signaling pathways that accompany CSF-1-induced spreading in normal osteoclasts. To explore the role c-src plays in these processes, we also studied osteoclasts prepared from animals with targeted disruption of the $s r c$ gene.

In normal osteoclasts, CSF-1 treatment induces rapid cytoplasmic spreading, with redistribution of F-actin from a well-delineated central attachment ring to the periphery of the cell. CSF-1 increases membrane phosphotyrosine staining in osteoclasts and induces the phosphorylation of several cellular proteins in cultured, osteoclast-like cells, including c-fms, c-src, and an 85-kD Grb2-binding protein. Src kinase activity is increased threefold after CSF-1 treatment.

In $s r c^{-}$cells, no attachment ring is present, and CSF-1 fails to induce spreading or a change in the pattern of F-actin distribution. Although c-fms becomes phosphorylated after CSF-1 treatment, the $85-\mathrm{kD}$ protein is significantly less phosphorylated in $\boldsymbol{s r c}^{-}$osteoclast-like cells.

These results indicate that c-src is critical for the normal cytoskeletal architecture of the osteoclast, and, in its absence, the spreading response induced by CSF-1 is abrogated, and downstream signaling from c-fms is altered. $(\mathrm{J}$. Clin. Invest. 1997. 100:2476-2485.) Key words: osteoclasts • colony-stimulating factor- $1 \cdot \mathrm{c}-\mathrm{fms} \cdot \mathrm{src} \cdot$ bone
\end{abstract}

\section{Introduction}

Osteoclasts are terminally differentiated, multinucleated cells that possess the ability to resorb both the inorganic and organic components of bone $(1,2)$. There is considerable interest in understanding how osteoclast function is regulated, because postmenopausal osteoporosis, a major public health problem in this country, is a disease characterized by excessive bone

Address correspondence to Dr. Karl L. Insogna, Fitkin I, P.O. Box 208020, 333 Cedar Street, New Haven, CT 06520-8020. Phone: 203785-5450; FAX: 203-785-6015; E-mail: karl_insogna@qm.yale.edu

Received for publication 11 November 1996 and accepted in revised form 26 September 1997.

J. Clin. Invest.

(C) The American Society for Clinical Investigation, Inc. 0021-9738/97/11/2476/10 \$2.00

Volume 100, Number 10, November 1997, 2476-2485

http://www.jci.org breakdown (3). Several systemically active hormones such as PTH regulate bone resorption in part by stimulating the local release of cytokines in bone that increase osteoclast number. Among these cytokines are GM-CSF, IL-1, IL-6, and IL-11 (4-11). Cytokines that regulate the function of mature osteoclasts have been less well-characterized.

Mature osteoclasts are motile cells (12). Recent work has identified colony-stimulating factor- $1(\mathrm{CSF}-1)^{1}$ as an important chemoattractant for mature osteoclasts $(13,14)$. Osteoclast migration is increased three- to eightfold by CSF-1 (13). CSF-1 also stimulates cytoplasmic spreading in these cells (14). It is now clear that, in vivo, CSF-1 is produced by bone cells in response to osteotropic hormones and has, as one of its targets, mature osteoclasts. Thus, treatment of rats with PTH leads to increased expression of CSF-1 in stromal and bone-lining cells immediately adjacent to mature osteoclasts, which express the receptor for CSF-1, c-fms (15). In situ hybridization and immunohistochemical studies have identified the mature osteoclast as the principal cell in bone-expressing receptors for CSF-1 $(16,17)$. In vitro, CSF-1 is secreted constitutively and in response to osteotropic hormones by cultured bone cells and appears to be the predominant colony-stimulating activity released in response to PTH (17-19). Taken together, these in vivo and in vitro data indicate that $\mathrm{CSF}-1$ produced by bone cells in response to PTH can regulate directly the activity of mature osteoclasts.

Therefore, we sought to understand better the effects of CSF-1 on mature osteoclasts. We chose to examine the spreading response, because this is a dramatic phenotypic change relevant to the chemoattractant effects of CSF-1, which we hypothesized would involve significant intracellular signaling and cytoskeletal changes.

The receptor for CSF-1, c-fms, is a receptor tyrosine kinase. Ligand-dependent receptor dimerization and activation lead to rapid tyrosine phosphorylation of selected cellular proteins and the recruitment of signaling molecules to the receptor $(20$, 21). Among these is c-src, a ubiquitous cellular tyrosine kinase (22). In cells engineered to overexpress c-fms, CSF-1 treatment induces c-src binding to $\mathrm{Tyr}^{561}$ (human sequence) in the cytoplasmic domain of c-fms, resulting in both an increase in src kinase activity and tyrosine phosphorylation of the protein $(23,24)$. This is of particular relevance to osteoclast biology, since c-src is known to be necessary for normal osteoclast function. Mice in which the src gene has been disrupted by homologous recombination exhibit an osteopetrotic phenotype (25). Osteoclast number is normal in $s r c^{-}$mice, but the cells cannot

1. Abbreviations used in this paper: CSF-1, colony-stimulating factor-1; GST, glutathione $S$-transferase; HRP, horseradish peroxidase; OCL, osteoclast-like cell. 
resorb bone despite the expression of other closely related src family members (26-29). The specific role src plays in osteoclasts, and how its kinase activity is regulated, are not yet known. Consequently, we examined the effects of CSF-1 in normal osteoclasts and in cells isolated from mice with targeted disruption of the $s r c$ gene. We were interested specifically in determining if CSF-1 could regulate src kinase activity in normal cells, and whether, in its absence, CSF-1 effects and signaling pathways would be altered. Another signaling molecule of importance in the c-fms signaling cascade is the $\mathrm{SH} 2 / \mathrm{SH} 3$ adapter protein Grb2, which is known to associate with c-fms after activation and plays an important role in linking receptor tyrosine kinases to the ras signaling pathway $(30,31)$.

Our results indicate that CSF-1 induces cytoplasmic spreading in normal osteoclasts, which is accompanied by rapid reorganization of the actin cytoskeleton. In normal osteoclast-like cells (OCLs), CSF-1 induces tyrosine phosphorylation of several cellular proteins, including c-fms, c-src, and an $85-\mathrm{kD}$, Grb2-binding protein. c-src kinase activity is also increased after CSF-1 treatment of OCLs. The pattern of proteins phosphorylated in response to CSF-1 is different in $\mathrm{Src}^{-}$OCLs, and $s r c^{-}$osteoclasts fail to spread in response to CSF-1. Taken together, these data demonstrate a critical role for c-src in controlling the osteoclast cytoskeleton, and are consistent with an important role for this kinase in mediating the spreading response induced by CSF-1 in these cells.

\section{Methods}

\section{Cell culture and assays using cultured cells}

Osteoclasts. Osteoclasts were isolated directly from the long bones of 1-d-old rats by mechanically disaggregating cells from minced bone and allowing them to settle on glass coverslips as described previously (32).

To prepare osteoclasts from normal and $\mathrm{src}^{-}$mice, 2-mm tail samples were obtained from litters of 1-d-old mice born to breeding pairs known to be heterozygous for the mutant $s r c^{-}$gene. (A colony of mice carrying the disrupted $s r c$ gene has been established at Yale University, using animals kindly provided to us by Dr. P. Soriano, Fred Hutchinson Cancer Research Center, Seattle, WA.) DNA was prepared, and PCR was performed in Gitschier buffer (33), using the methods reported by Thomas et al. (34). Each PCR reaction contained three primers: exon 2 primer, 5'-AGCAACAAGAGCCAGCCCAAGGAC-3'; exon 2-3 reverse primer, 5'-GTGACGGTGTCCGAGGAGTTGAAG-3'; and neo-5' reverse primer, 5'-TCATAGCCGAATAGCCTCTCCAC- $3^{\prime}$. The first two primers generate a PCR product of $200 \mathrm{bp}$ in genotypically normal animals. The first and third primers generate a PCR product of $400 \mathrm{bp}$ in $\mathrm{src}^{-}$mice. Osteoclasts were prepared from genotypic $s r c^{-}$newborns and compared to cells isolated from genotypically normal newborns.

Osteoclasts isolated directly from bone tissue are referred to in the text as osteoclasts. Cells generated in vitro using the coculture system described below are referred to in the text as OCLs.

OCLs. OCLs were prepared by coculturing primary murine osteoblasts with marrow and/or spleen cells as described previously by Akatsu et al. (35). Primary murine osteoblasts were obtained by serial collagenase/dispase digestion of neonatal mouse calvariae. 50 calvariae were dissected from neonatal mice, pooled, and subjected to sequential digestion with $0.1 \%$ bacterial collagenase (Boehringer Mannheim Biochemicals, Indianapolis, IN) and $0.2 \%$ dispase (Boehringer Mannheim Biochemicals). Digestions were for $10 \mathrm{~min}$ at $37^{\circ} \mathrm{C}$ with rapid shaking. Digests $2-5$ were pooled, plated into $100-\mathrm{mm}$ dishes, allowed to come to confluence, trypsinized, and cryopreserved at a concentration of $2 \times 10^{6} \mathrm{cells} / \mathrm{ml}$. For use in the coculture system, osteoblasts were plated at an initial density of $2.5 \times 10^{4}$ cells $/ \mathrm{cm}^{2}$.
Murine bone marrow was obtained for coculture from adult 4-6-wk-old CD1 mice, and from $s r c^{-}$mice and their normal littermates, by dissection of the tibiae, removal of the epiphyses, and flushing the marrow cavity with a 27 -gauge needle. Marrow cells were collected in $\alpha$-MEM. Cells were sedimented, resuspended in the same medium containing $10 \%$ FCS, counted, and plated at an initial density of $1.5 \times 10^{5}$ cells $/ \mathrm{cm}^{2}$.

Because of the reduced marrow space in $s r c^{-}$mice, cocultures prepared from these animals and their normal littermates used bone marrow cells, isolated as described above, supplemented with splenocytes. Splenocytes were prepared from 6-wk-old $s r c^{-}$mice and their normal littermates, since mortality is high in $\mathrm{src}^{-}$mice after this age. A cell suspension was prepared from pooled, mechanically disaggregated spleens and filtered through $50-\mu \mathrm{m}$ sterile nylon mesh. These cells were pooled with the marrow cells, counted, and used at a concentration of $5 \times 10^{6}$ cells $/ \mathrm{cm}^{2}$.

OCLs were prepared by seeding primary osteoblasts at an initial density of $2.5 \times 10^{4}$ cells $/ \mathrm{cm}^{2} 2 \mathrm{~h}$ before the addition of marrow. Marrow cells (at an initial density of $1.5 \times 10^{5} \mathrm{cells} / \mathrm{cm}^{2}$ ) or the marrow/ splenocyte mixtures (at an initial density of $5 \times 10^{6} / \mathrm{cm}^{2}$; range of ratio 1:50-1:75) were then added, and the mixture was cocultured for $6 \mathrm{~d}$ in the presence of $10^{-8} \mathrm{M} 1,25$-dihydroxyvitamin $\mathrm{D}_{3}$ with a medium change ( $\alpha$-MEM with $10 \%$ FCS, $1 \%$ penicillin/streptomycin, $1 \%$ L-glutamine, $20 \mathrm{mM}$ Hepes, $\mathrm{pH}$ 7.36) every other day. At 5-6 d, contaminating mononuclear cells were removed by treatment with $0.1 \%$ EDTA at $37^{\circ} \mathrm{C}$ for $5 \mathrm{~min}$. This results in a preparation with $\sim 90 \%$ of the cellular material comprised solely of OCLs. OCLs possess the important phenotypic and biochemical markers of authentic osteoclasts. They stain strongly for tartrate-resistant acid phosphatase, express calcitonin receptors, and, most importantly, can resorb bone (35).

\section{Cell spreading assay}

Cell spreading was assessed in real time using a phase-contrast microscope with a Hoffman objective (Modulation Optics Inc., Greenvale, NY). Cells were isolated in $\alpha$-MEM with $10 \%$ FCS and allowed to attach for $2 \mathrm{~h}$ to glass coverslips (which had been acid-washed and incubated overnight in $30 \%$ FCS). The concentration of FCS was then reduced to $2 \%$ for $3 \mathrm{~h}$. The cells were treated with $2.5 \mathrm{nM} \mathrm{CSF}-1$ in $\alpha$-MEM with $0.1 \%$ BSA, $20 \mathrm{mM}$ Hepes, $\mathrm{pH} 7.36$, at room temperature and photographed at the intervals indicated in Results. To quantitate cell spreading, images were scanned into a Power Macintosh 7100/80AV using an Arcus II flatbed scanner (Agfa Division, Bayer Corp., Ridgefield Park, NJ), and the planar area of each cell was determined using the National Institutes of Health Image 1.59b1 software program.

\section{Phalloidin staining of osteoclasts}

Neonatal rat osteoclasts and osteoclasts isolated from $\mathrm{src}^{-}$or normal littermates of $s r c^{-}$mice were isolated on glass coverslips as described in the preceding paragraph. The cells were then treated with vehicle or $2.5 \mathrm{mM} \mathrm{CSF}-1$ at room temperature for $10 \mathrm{~min}$, and fixed and stained with rhodamine conjugated to phalloidin using the following protocol. Coverslips were washed twice with PBS, fixed for $10 \mathrm{~min}$ in $3.7 \%$ formaldehyde in PBS, extracted with $-20^{\circ} \mathrm{C}$ acetone for $3 \mathrm{~min}$, and air dried. $5 \mu \mathrm{l}$ of rhodamine phalloidin stock solution (Molecular Probes, Inc., Eugene, OR) was dried, reconstituted in $200 \mu$ of PBS, and placed on the coverslips for $20 \mathrm{~min}$ at room temperature. The slides were twice washed rapidly with PBS and mounted in 1:1 PBS/ glycerol for confocal microscopy.

\section{Quantitation of phosphotyrosine staining in osteoclasts}

Osteoclasts isolated on coverslips were treated with 0.1 or $0.5 \mathrm{nM}$ CSF-1 for 1-5 min and then fixed for $10 \mathrm{~min}$ with $3.7 \%$ formaldehyde in PBS. The coverslips were washed with PBS, rapidly dehydrated and rehydrated through graded ethanol solutions, and blocked in 5\% normal goat serum (Boehringer Mannheim Biochemicals) in PBS containing $0.05 \%$ saponin. The coverslips were then incubated in $\mathrm{mAb}$ to phosphotyrosine (Upstate Biotechnology, Inc., Lake Placid, 
$\mathrm{NY}$ ) at a 1:50 dilution for $2 \mathrm{~h}$, washed, and incubated in fluoresceinconjugated secondary antibody (1:100) for $1 \mathrm{~h}$. Coverslips were mounted in Flurosave (Calbiochem Corp., San Diego, CA) and analyzed by confocal microscopy. Optical slices of $2-2.5 \mu \mathrm{M}$ in thickness were taken at a distance of $1.5-2.5 \mu \mathrm{M}$ above the plane of adherence. Maximum pixel intensity was quantitated using a confocal microscope with a krypton laser (model MRC600; Bio-Rad Laboratories, Richmond, CA).

\section{Treatment of OCLs with CSF-1 and preparation of cell lysates}

After purification, OCLs were allowed to recover in $\alpha$-MEM with $1 \%$ FCS, $1 \%$ penicillin/streptomycin, $1 \%$ L-glutamine, $20 \mathrm{mM}$ Hepes, $\mathrm{pH}$ 7.36 , for $30 \mathrm{~min}$. The medium was then aspirated, and the cells were treated at room temperature with $\alpha$-MEM containing $20 \mathrm{mM}$ Hepes, $\mathrm{pH} 7.36,1 \%$ L-glutamine, $0.1 \%$ BSA, and either vehicle or $2.5 \mathrm{nM}$ CSF-1. After treatment, cells were washed twice with ice-cold PBS and lysed in RIPA buffer (36) containing protease and phosphatase inhibitors ( $1 \mathrm{mM}$ PMSF, $1 \mu \mathrm{g} / \mathrm{ml}$ pepstatin, $10 \mu \mathrm{g} / \mathrm{ml}$ leupeptin, $10 \mu \mathrm{g} /$ $\mathrm{ml}$ aprotinin, $1 \mathrm{mM}$ sodium vanadate, and $500 \mathrm{mM}$ sodium fluoride). In most experiments, OCLs were prepared in 10-cm-diameter dishes, lysed with $300 \mu \mathrm{l}$ of lysis buffer, and typically yielded $500 \mu \mathrm{g}$ of protein per dish. To examine the proteins that associate with Grb2 after CSF-1 treatment, OCLs were lysed in HTNG lysis buffer $(50 \mathrm{mM}$ Hepes, $\mathrm{pH}$ 7.5, $150 \mathrm{mM} \mathrm{NaCl}, 1.5 \mathrm{mM} \mathrm{MgCl} 2,1 \mathrm{mM}$ EGTA, $1 \%$ Triton, $10 \%$ glycerol) containing the same mixture of inhibitors. The lysates were vortexed for $1 \mathrm{~min}$, rocked for $1 \mathrm{~h}$ at $4^{\circ} \mathrm{C}$, and cellular debris was removed by centrifugation $\left(10 \mathrm{~min}\right.$ at $4^{\circ} \mathrm{C}$ using an Eppendorf microfuge at a relative centrifugal force of 16,000). Protein content was determined, and the lysates were either used immediately or frozen at $-70^{\circ} \mathrm{C}$ until use.

\section{Immunoprecipitation and Western blotting}

To analyze whole cell lysates, equivalent amounts of protein were electrophoresed by SDS-PAGE, transferred to nitrocellulose, and probed sequentially with an appropriate primary antibody followed by horseradish peroxidase (HRP)-coupled secondary antibody. Detection was by enhanced chemiluminescence and fluorography. Fluorographs were quantitated using a Visage 2000 image analyzer (Bioimage Products, Ann Arbor, MI) calibrated to an external standard.

Immunoprecipitation studies were performed using antibodies either noncovalently bound or conjugated to protein $\mathrm{G}$-agarose beads as detailed in the figure legends. Equivalent amounts of cell lysates were incubated with coupled antibody for $1-2 \mathrm{~h}$ at $4^{\circ} \mathrm{C}$, and the beads were washed three times with RIPA buffer and boiled in $2 \times$ Laemmli sample buffer before electrophoresis. Preclearing of lysates before immunoprecipitation studies was not done except when examining the proteins associated with Grb2.

For studies examining the proteins associated with Grb2 in vivo, lysates prepared in HTNG buffer were precleared with nonimmune rabbit serum and then incubated either with nonimmune rabbit serum or antibody to Grb2 for $2 \mathrm{~h}$ at $4^{\circ} \mathrm{C}$. $50 \mu \mathrm{l}$ of protein $\mathrm{G}$-agarose beads was then added, and the incubation was continued for an additional $1 \mathrm{~h}$. The beads were then washed in HTNG wash buffer $(20 \mathrm{mM}$ Hepes, pH 7.5, $150 \mathrm{mM} \mathrm{NaCl}, 0.1 \%$ Triton, $10 \%$ glycerol) and boiled in $2 \times$ Laemmlli sample buffer before electrophoresis.

\section{In vitro binding to GST-Grb2 (glutathione S-transferase-Grb2)}

A GST-Grb2 fusion protein comprising the entire Grb2 coding sequence was prepared and purified as described (37). Unstimulated or CSF-1-stimulated $\mathrm{src}^{+}$OCL lysates $(1 \mathrm{mg} / \mathrm{ml}$ prepared in RIPA lysis buffer) were incubated with $10 \mu \mathrm{g}$ of GST-agarose beads at $4^{\circ} \mathrm{C}$ for $2 \mathrm{~h}$. The beads were removed, and the precleared supernatant was incubated with $10 \mu \mathrm{g}$ GST-Grb2 beads for $4 \mathrm{~h}$ at $4^{\circ} \mathrm{C}$. GST-Grb2bound material was washed four times in RIPA buffer. The bound proteins and those remaining in the supernatant were analyzed by Western blotting with antiphosphotyrosine antibody.

\section{In vitro src kinase assays}

Lysates for in vitro src kinase assays were prepared as reported previously (29). Briefly, samples were lysed in RIPA buffer, and equal amounts of protein, 50-200 $\mu \mathrm{g}$, were incubated with an mAb to c-src coupled to protein $\mathrm{G}$-agarose for $60 \mathrm{~min}$ on ice. The beads were washed twice with RIPA buffer and once with $100 \mathrm{mM} \mathrm{NaCl}, 10 \mathrm{mM}$ Tris, $\mathrm{pH}$ 7.0.

Kinase activity was assessed using a nonradioactive tyrosine kinase ELISA assay kit from Boehringer Mannheim Biochemicals. The recommended protocol for assaying immunoprecipitates was used with the following modifications: (a) c-src was immunoprecipitated as above, reconstituted in $50 \mu \mathrm{l}$ of $100 \mathrm{mM} \mathrm{NaCl}, 10 \mathrm{mM}$ Tris, $\mathrm{pH} 7.0$, and $10-\mu 1$ aliquots assayed in duplicate. $10-\mu l$ aliquots were analyzed by SDS-PAGE to ensure that equivalent amounts of protein were added to each reaction; $(b)$ the substrate concentration used was 20 $\mathrm{nM}$; and $(c)$ the incubation time was $75 \mathrm{~min}$ at $37^{\circ} \mathrm{C}$. The oligopeptide used as substrate represents the first 17 amino acids of gastrin, biotinylated at its amino terminus. The single letter amino acid sequence for this substrate is: Bi-EGPWLEEEEEAYGWMDF.

\section{Measurement of protein concentration}

Protein concentrations in cell lysates were estimated using the DC protein assay kit (Bio-Rad Laboratories) following the manufacturer's recommended protocol.

\section{Antibodies}

$\mathrm{mAbs}$ to c-src were obtained from Oncogene Science, Inc. (Manhasset, NY). mAbs to phosphotyrosine (clone 4G10) and polyclonal antibodies to c-fms were purchased from Upstate Biotechnology Inc. Antisera to Grb2 and c- $c b l$ were obtained from Santa Cruz Biotechnology, Inc. (Santa Cruz, CA). HRP-conjugated goat anti-mouse IgG antibody was obtained from Promega Corp. (Madison, WI), and HRP-conjugated goat anti-rabbit IgG antibody was obtained from Bio-Rad Laboratories.

Rhodamine-conjugated phalloidin was obtained from Molecular Probes, Inc.

\section{CSF-1}

Recombinant human CSF-1 (specific activity $1.9 \times 10^{6} \mathrm{U} / \mathrm{mg}$ in the murine bone marrow colony assay) was a generous gift from Genetics Institute, Inc. (Cambridge, MA).

\section{Results}

CSF-1 induces rapid cytoplasmic spreading and actin cytoskeletal reorganization in normal but not src $\mathrm{c}^{-}$osteoclasts. As shown in Fig. 1, panel I, CSF-1 treatment of neonatal rat osteoclasts results in a rapid induction of cytoplasmic spreading. By 5 min (panel $I, D$ ), a prominent cytoplasmic ridge has appeared from which the cell subsequently spreads. Panel $I I$ demonstrates the typical response seen in an osteoclast isolated from normal littermates of $s r c^{-}$mice. Again, by 5 min (panel $I I, D$ ), one sees the appearance of a cytoplasmic ridge from which the cell subsequently spreads. In contrast, as illustrated in panel $I I I$, formation of a cytoplasmic ridge and/or spreading were not observed in osteoclasts derived from $s c^{-}$mice. In panel $I$, the cell area before CSF-1 treatment was 7.12 arbitrary pixel units, and after was 10.71 , representing a final area $150 \%$ of control. In panel $I I$, before CSF-1 treatment, the mean area was 8.08 , and after was 9.31, representing a final area $115 \%$ of control. In panel $I I I$, the area before treatment was 5.06 and after was 4.99 , representing a final area $98 \%$ of control. In six normal mouse osteoclasts, the mean cell area after 10 min of CSF-1 treatment was $135 \pm 14 \%$ compared with the pretreatment cell area, whereas vehicle alone induced no change in cell area (mean cell area after treatment was $96 \pm 9 \%$ of the pretreat- 
PANEL I

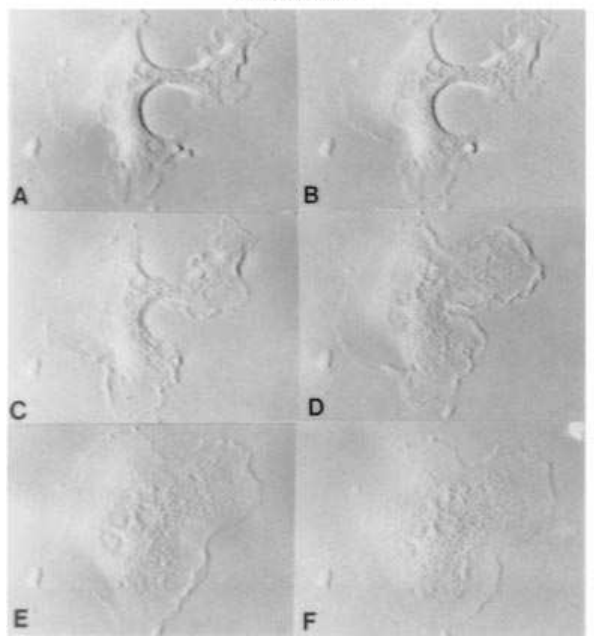

PANEL II

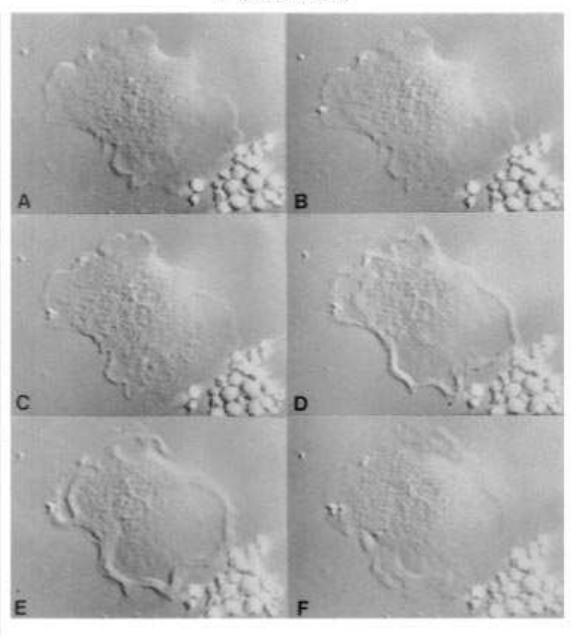

PANEL III

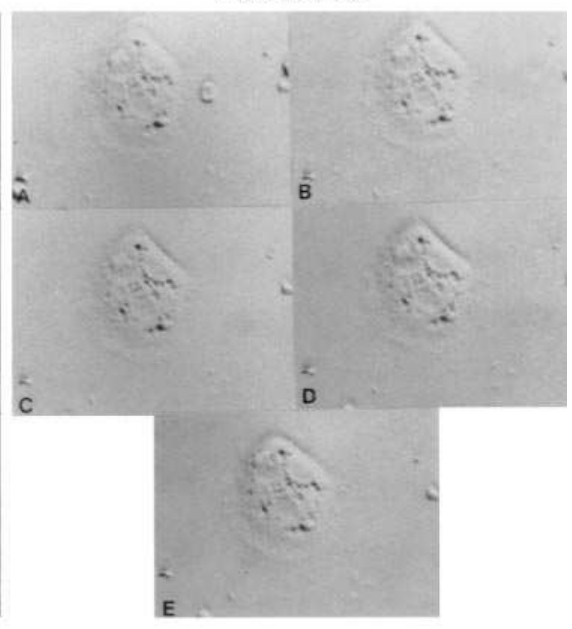

Figure 1. CSF-1 induces spreading in normal but not $\mathrm{src}^{-}$osteoclasts. Typical response of a neonatal rat osteoclast (panel $I$ ), an osteoclast from a $+/$ ? mouse (panel $I I$ ), and an osteoclast from a $-/-$ mouse (panel $I I I)$ to $2.5 \mathrm{nM} \mathrm{CSF-1.} \mathrm{Time} 0(A), 30 \mathrm{~s}(B), 2 \mathrm{~min}(C), 5 \mathrm{~min}(D), 10 \mathrm{~min}(E)$, and $15 \mathrm{~min}(F)$ after treatment with CSF-1. Note appearance of a ridge at the edge of the cell in panel $I, D$, and the disappearance of the invagination on the right side of the cell with treatment. Note similar changes in panel $I I$ and the lack of changes in panel $I I I$.

ment area; $n=5$ ). In $s r c^{-}$osteoclasts, the mean cell area after treatment with CSF-1 was $92 \pm 3 \%$ of the pretreatment area; $n=7$. The increment in cell area was significantly greater after CSF-1 treatment in wild-type than in $\operatorname{src}^{-}$osteoclasts $(P<0.01)$.

The striking morphologic changes induced by CSF-1 in normal osteoclasts suggest that this growth factor induces rapid changes in the actin cytoskeleton. As shown in Fig. 2, CSF-1 indeed causes a change in the pattern of F-actin staining by phalloidin in osteoclasts. Osteoclasts from normal animals, allowed to settle on glass coverslips, form a ring of F-actin analogous to the sealing zone these cells form in bone $(A)$. After 10 min of CSF-1 treatment $(B)$, this ring is no longer visible, and there is an apparent redistribution of F-actin to the extreme periphery of the cell, consistent with the spreading phenomenon noted in Fig. 1. At baseline, $80 \%$ of cells had fully developed actin rings. In four experiments, after treatment with CSF-1, 67 $\pm 4 \%$ had no discernible actin rings, $26 \pm 1 \%$ had slight residual ring formation, and from $0-7 \%$ had persistent detectable actin rings. The number of cells demonstrating persistent, complete actin ring formation after CSF-1 treatment was significantly less than after vehicle treatment $(P<$ $0.001)$. By contrast, in $s r c^{-}$cells $(C$ and $D)$, there is no discrete F-actin ring before CSF-1 treatment and no apparent redistribution of actin after exposure to CSF-1.

CSF-1 increases tyrosine-phosphorylation in osteoclasts. As noted, the receptor for CSF-1, c-fms, is a receptor tyrosine kinase that signals via rapid tyrosine phosphorylation of selected cellular proteins.

Therefore, confocal microscopy was used to examine the effects of CSF-1 on tyrosine phosphorylation in isolated neonatal rat osteoclasts. As illustrated in Fig. 3, plasma membrane phosphotyrosine labeling increased over a time course of 5 min. The increase was significant at $5 \mathrm{~min}$ at the lower dose, and significant at both 1 and $2.5 \mathrm{~min}$ at the higher dose of CSF-1, consistent with a more rapid induction of phosphotyrosine labeling at the higher CSF-1 concentration.

Given the fact that these cells are known to express the re- ceptor for CSF-1 in vivo and the rapid time course of the response, these data indicate that c-fms is functionally active in osteoclasts, and that CSF-1 is acting directly on these cells.
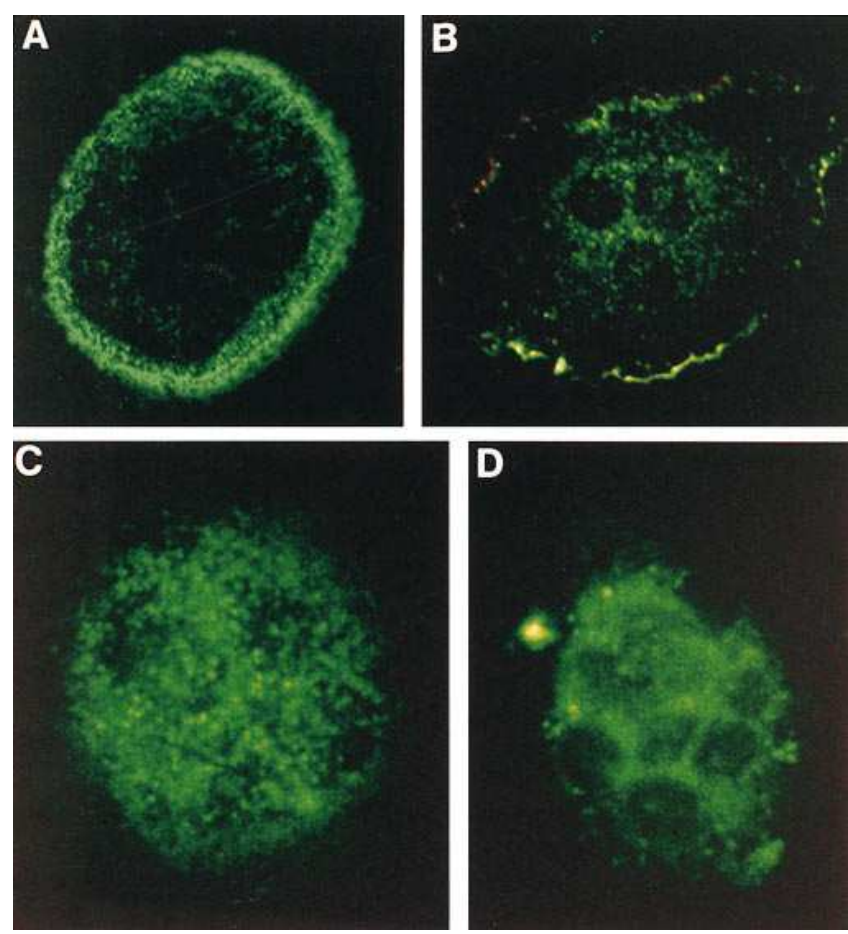

Figure 2. CSF-1 induces changes in the actin cytoskeleton of osteoclasts. Phalloidin staining of normal and $s r c^{-}$osteoclasts before ( $A$ and $C$ ) and after ( $B$ and $D$ ) treatment for 10 min with $2.5 \mathrm{nM} \mathrm{CSF-1}$ as assessed by confocal microscopy. Note redistribution of phalloidin staining to the periphery of the normal cell after CSF-1 treatment in $B$, and the failure of CSF-1 to induce changes in the staining pattern in $\mathrm{src}^{-}$cells in $D$. 

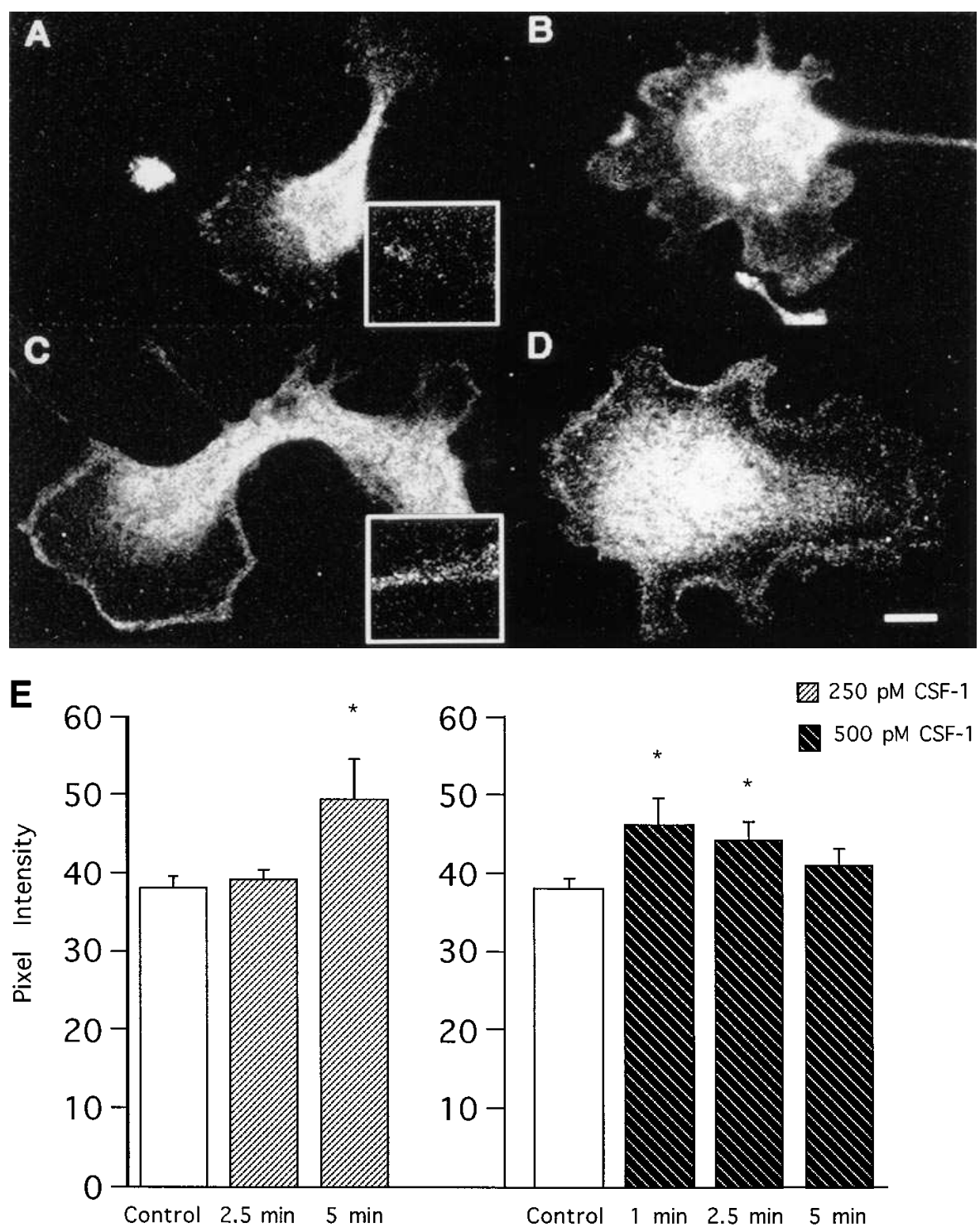

Figure 3. CSF-1 increases plasma membrane phosphotyrosine labeling in osteoclasts. $(A-D)$ Increase in plasma membrane phosphotyrosine labeling in osteoclasts after treatment with CSF-1. Control $(A), 30 \mathrm{~s}(B), 2 \mathrm{~min}(C)$, and $5 \mathrm{~min}$ $(D)$ of CSF-1 treatment. Framed areas highlight the increase in plasma membrane labeling; bar $=5 \mu \mathrm{m}$. (E) Effect of CSF-1 on mean pixel intensity in isolated neonatal rat osteoclasts at various times after treatment. 9-13 osteoclasts were analyzed at each time point, and the experiment was repeated three times. Pixel intensity was quantitated over the plasma membrane of each cell by confocal microscopy. ${ }^{*} P<0.05$ compared to control.
CSF-1 induces labeling of selected proteins in OCLs. Since authentic osteoclasts cannot be isolated in sufficient numbers to explore the biochemistry of this phenomenon, OCLs were prepared, purified, and treated with CSF-1. Fig. 4, $A$ and $B$, shows the pattern of proteins tyrosine phosphorylated in response to CSF-1 treatment for either $30 \mathrm{~s}, 2 \mathrm{~min}$, or $5 \mathrm{~min}$. As can be seen, several proteins are selectively tyrosine-phosphorylated in a time-dependent manner after CSF-1 treatment. We focused on three proteins that most consistently became tyrosine phosphorylated: a 165- (A), an 85-90- (B), and a 60-kD protein $(\mathrm{C})$. Because of its intense tyrosine phosphorylation, it is difficult to appreciate changes in staining intensity of protein $\mathrm{C}$ in Fig. $4 A$. Therefore, in a separate experiment shown in Fig. $4 B$, a very short exposure of the whole cell lysate Western blot is shown that illustrates better the increase in tyrosine phosphorylation of protein C after treatment with CSF-1.

The molecular mass and the rapid time course of tyrosine phosphorylation after exposure to CSF-1 suggested that the 165-kD protein was c-fms. Fig. 5 illustrates a Western blot of immunoprecipitated c- $f m s$ at various times after CSF-1 treatment, probed with an $\mathrm{mAb}$ to phosphotyrosine. As can be seen, c-fms indeed becomes phosphorylated rapidly by 2 min and is then dephosphorylated rapidly by $5 \mathrm{~min}$.

Although CSF-1 treatment has been reported to induce activation of c-src in cells that overexpress the CSF-1 receptor, this has not been reported in nontransfected cells. As shown in Fig. 4 B, right panel, when the phosphotyrosine blot shown in the left panel is stripped and reprobed for c-src, it would appear that protein $\mathrm{C}$ is c-src. To confirm this, c-src was immunoprecipitated from OCL whole cell lysates at various times after CSF-1 treatment. As shown in Fig. 6, c-src becomes tyrosine phosphorylated progressively in response to CSF-1 treatment, with maximum phosphorylation noted between 2 and 5 min. The densitometric value at $5 \mathrm{~min}$ is 2.4 -fold greater than that of the control value. (The bottom panel in Fig. 6 demonstrates equal loading of c-src protein in each lane.) Furthermore, the CSF-1-dependent increase in the phosphotyrosine content of c-src was accompanied by a time-dependent increase in src kinase activity (Fig. 7), with a maximal effect noted at 5 min where catalytic activity was increased to a value 2.9-fold greater than control $(P=0.05$ vs. baseline $)$.

We have reported recently that the $120-\mathrm{kD}$ protooncogene, 

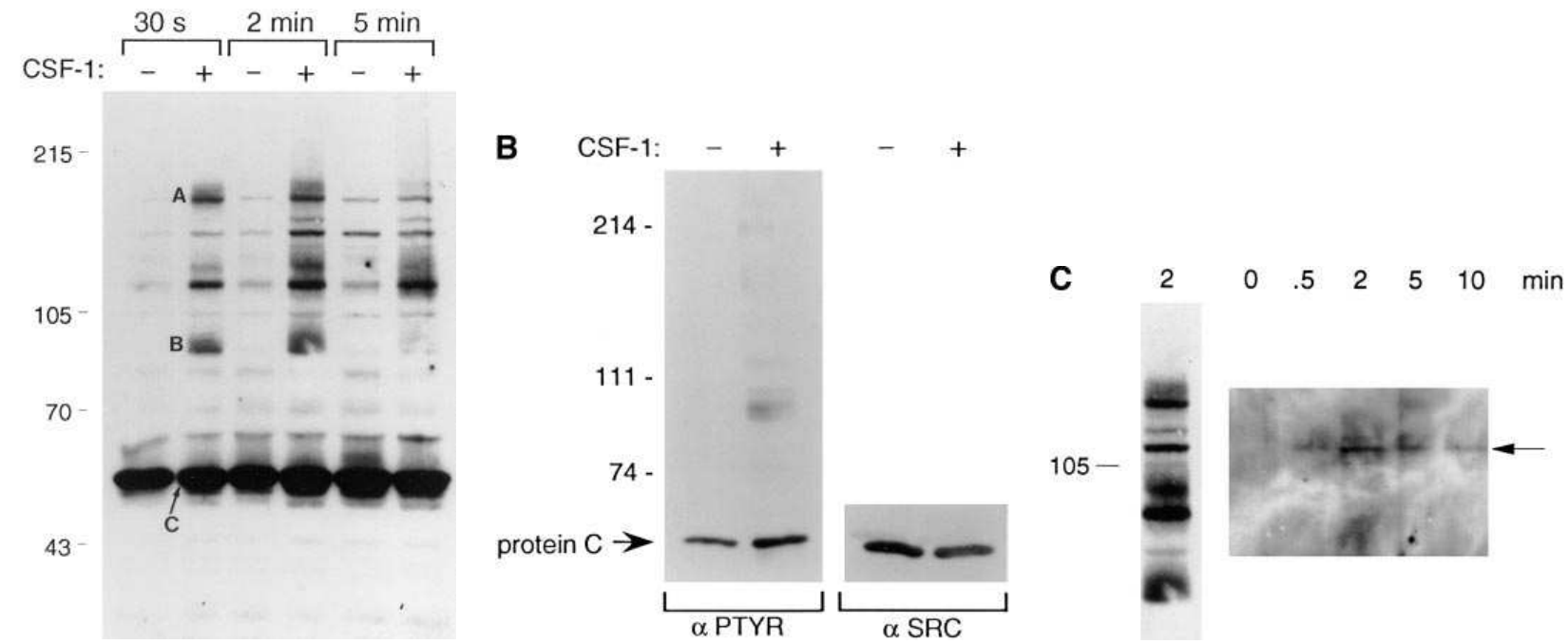

Figure 4. (A) CSF-1 induces phosphorylation of selected cellular proteins in OCLs. Pattern of proteins tyrosine phosphorylated in OCLs after treatment with $2.5 \mathrm{nM} \mathrm{CSF}-1(+)$ or with vehicle alone $(-) .50 \mu \mathrm{g} / \mathrm{lane}$ of whole cell lysates were separated by SDS-PAGE, transferred to nitrocellulose, and probed with an $\mathrm{mAb}$ to phosphotyrosine as described in Methods. The antiphosphotyrosine antibody was used at a final concentration of $1 \mu \mathrm{g} / \mathrm{ml}$, and the HRP-conjugated secondary antibody was used at a final concentration of $50 \mathrm{ng} / \mathrm{ml}$. Protein $A$ refers to the $165-\mathrm{kD}$ phosphoprotein, protein $B$ to the $85-\mathrm{kD}$ phosphoprotein, and $C$ to the intensely phosphorylated $60-\mathrm{kD}$ protein, seen better in $4 B$. ( $B$ ) CSF- 1 induces tyrosine phosphorylation of a $60-\mathrm{kD}$ protein. Whole cell lysates, $50 \mu \mathrm{g} / \mathrm{lane}$, before and $5 \mathrm{~min}$ after CSF-1 treatment were Western blotted with antiphosphotyrosine antibody (left) and developed after $15 \mathrm{~s}$. The same blot (right) was stripped and reprobed for c-src, confirming that the increase in phosphotyrosine staining is not due to a loading effect. The final concentration of c-src antibody for Western blotting was $0.3 \mu \mathrm{g} / \mathrm{ml}$. (C) CSF-1 induces tyrosine phosphorylation of c-cbl. (Left) Phosphotyrosine Western blot of $50 \mu \mathrm{g}$ of whole cell lysate from OCLs treated for 2 min with CSF-1. (Right) Phosphotyrosine Western blot of c-cbl immunoprecipitated from OCL lysates prepared from cells treated with $2.5 \mathrm{nM}$ CSF-1 for $0,0.5,2,5$, and $10 \mathrm{~min}$. c-cbl was immunoprecipitated from $300 \mu \mathrm{g}$ of lysate per time point using $1 \mu \mathrm{g}$ of unconjugated antibody per sample.

c- $c b l$, is tyrosine phosphorylated in OCLs (38). As shown in Fig. $4 C$, in response to CSF-1, tyrosine phosphorylation of c- $c b l$ occurs. Thus, the observed increase in tyrosine phosphorylation of a $120-\mathrm{kD}$ protein in whole cell lysates of CSF-1treated OCLs (Fig. $4 A$ ) is due, at least in part, to tyrosine phosphorylation of c-cbl.

The pattern of proteins tyrosine phosphorylated in response to CSF-1 is altered in src ${ }^{-}$OCLs. As demonstrated in Figs. 1 and 2, osteoclasts that lack c-src do not develop an attachment ring and fail to spread or undergo actin reorganization after CSF-1 treatment. To begin to explore the biochemical basis for

$$
\text { Min }
$$

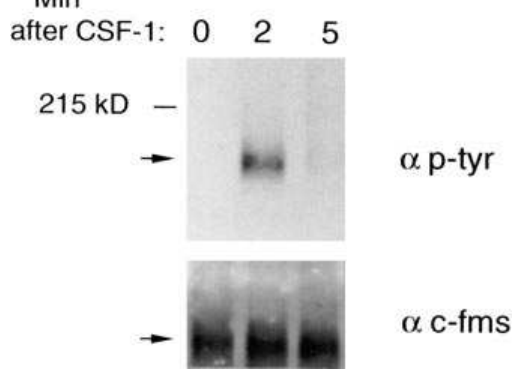

Figure 5. (Top) CSF-1 induces tyrosine phosphorylation of c-fms. OCLs were treated with $2.5 \mathrm{mM}$ CSF-1 for 0,2 , or $5 \mathrm{~min}$ and then lysed in RIPA buffer as described in Methods. c-fms was immunoprecipitated from $100 \mu \mathrm{g} /$ lane of whole cell lysate, separated by SDS-
PAGE, transferred to nitrocellulose, and probed with an mAb to phosphotyrosine as described in the legend to Fig. 4. c-fms was immunoprecipitated using $6 \mu \mathrm{l}$ of unconjugated polyclonal antibody. (Bottom) The same blot was then stripped and reprobed with antic-fms antibody (final dilution 1:1,000) to demonstrate equivalent amounts of protein in each lane. this altered cytoskeletal response to CSF-1, we next examined the pattern of proteins tyrosine phosphorylated in response to this growth factor in OCLs prepared from $\mathrm{src}^{-}$mice. As shown in Fig. 8, the pattern of tyrosine-phosphorylated proteins is different in $s c^{-}$mice, both before and after CSF-1 treatment. Despite the absence of c-src, some of the proteins that became tyrosine phosphorylated after CSF-1 treatment in wild-type cells also became phosphorylated in the $s r c^{-}$cells, indicating that initial dimerization of the receptor and activation of its cytoplasmic tyrosine kinase domain occur in the absence of src.

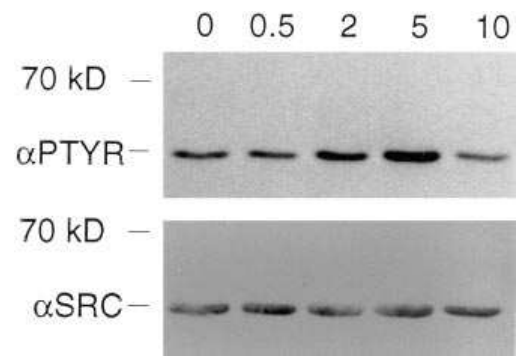

Figure 6. CSF-1 induces tyrosine phosphorylation of c-src. (Top) c-src was immunoprecipitated from $50 \mu \mathrm{g} /$ lane OCL lysates at various times after treatment with CSF-1, separated by SDS-PAGE, transferred to nitrocellulose, and probed with an

mAb to phosphotyrosine. (Bottom) The blot shown in the upper panel was stripped and reprobed with an antibody to c-src to demonstrate that equal amounts of c-src are present. Densitometric scanning of both lanes indicates a 2.4-fold increase in phosphotyrosine staining intensity at $5 \mathrm{~min}$. c-src was immunoprecipitated from $100 \mu \mathrm{g}$ of lysate per time point using $12 \mu \mathrm{l}$ of antibody conjugated to protein $\mathrm{G}-$ Sepharose. Phosphotyrosine staining was performed as described in the legend to Fig. 4. 


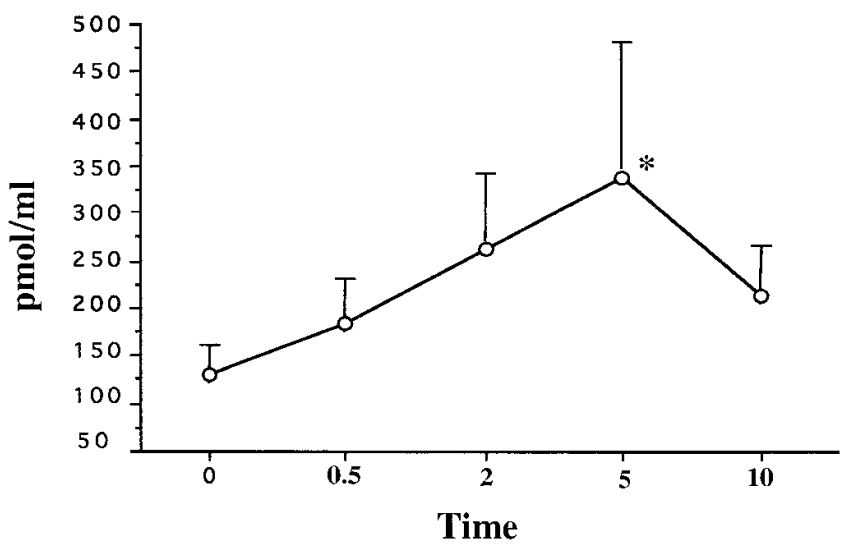

Figure 7. CSF-1 treatment increases c-src kinase activity. Mean data from five separate in vitro kinase assays performed using c-src immunoprecipitated from OCL lysates at various times after treatment with $2.5 \mathrm{nM} \mathrm{CSF}-1$. The increase in c-src kinase activity was analyzed by an unpaired $t$ test. Since five independent time course experiments were conducted, each from a different OCL preparation, there was variability in the basal activity in each preparation. Therefore, to make comparison among the different preparations possible, data were expressed as percentage of control. The mean absolute value at baseline was $130 \pm 32 \mathrm{pmol} / \mathrm{ml}$ of phosphorylated substrate, and the value 5 min after CSF- 1 treatment was $341 \pm 142$. $* P<0.05$ compared to baseline kinase activity. Mean densitometric values (in units of integrated signal intensity) for Western blots run as loading controls were not statistically different at any time point: $0=0.90 \pm 0.54,0.5$ $\min =0.91 \pm 0.44,2 \mathrm{~min}=1.60 \pm 0.66,5 \mathrm{~min}=1.62 \pm 0.79,10 \mathrm{~min}=$ $0.71 \pm 0.41$.

These include c-fms and an unidentified $110-\mathrm{kD}$ protein. However, a few proteins, most notably protein $\mathrm{B}$, are significantly less phosphorylated after CSF-1 treatment of the $s r c^{-}$cells. As expected, protein $\mathrm{C}$ was not seen in phosphotyrosine blots prepared from $s r c^{-}$OCLs, consistent with this protein being c-src. In the aggregate, these data suggest that the absence of $s r c$ alters downstream signaling from activated c-fms.

The 85-kD phosphoprotein binds Grb2. It has been reported previously that the intracellular signaling complex that

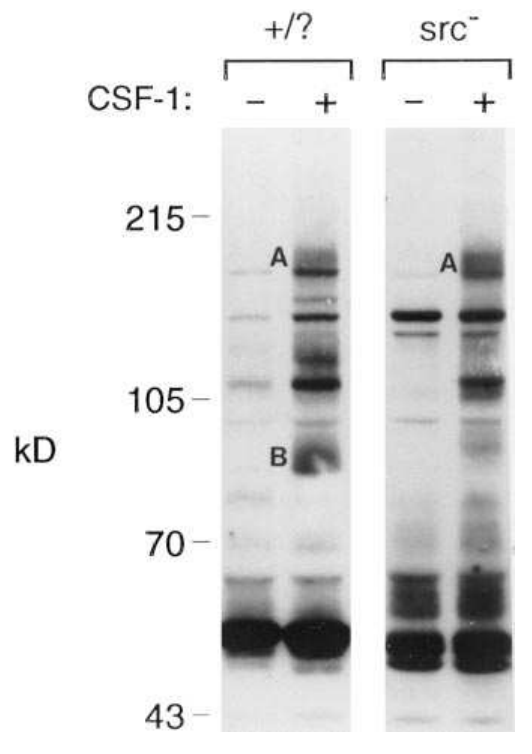

Figure 8. Effect of CSF-1 treatment on the pattern of proteins tyrosine phosphorylated in normal $(+/$ ? $)$ and $\mathrm{src}^{-}$OCLs. Analysis was performed after 2 min of treatment with $2.5 \mathrm{nM}$ CSF-1 as described in Fig. 4.

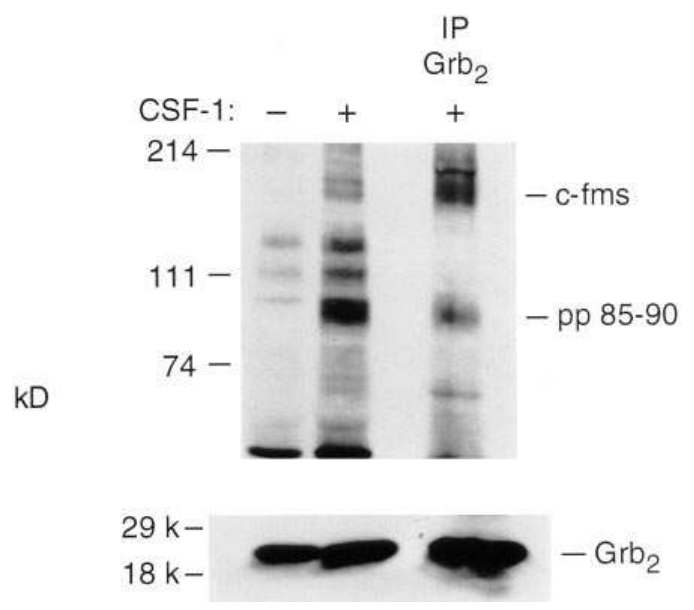

Figure 9. Phosphoprotein 85-90 ( $p p$ 85-90) is a Grb2-binding protein. Phosphotyrosine western blot of whole cell lysates before (left) and after (middle) 2 min of CSF-1 treatment. Right, Immunoprecipitate $(I P)$ of Grb2 from $450 \mu \mathrm{g}$ of whole cell lysate from cells treated with CSF-1 for 2 min. Nondissociative HTNG buffer (see Methods) was used for lysis and for immunoprecipitation studies. Grb2 was immunoprecipitated using $1 \mu \mathrm{g}$ of unconjugated antibody. Bottom, Presence of Grb2 in each lane when the blot is stripped and reprobed for Grb2.

forms after c-fms activation includes the adapter protein Grb2 (39). Grb2 binds via its $\mathrm{SH} 2$ domain to $\mathrm{Tyr}^{697}$ in the cytoplasmic domain of murine c-fms, and in turn associates with several proteins that become tyrosine phosphorylated after ligand binding (31). To explore the phosphoproteins that associate with Grb2 in OCLs, Grb2 was immunoprecipitated from whole cell lysates before and after CSF-1 treatment, subjected to Western blotting, and probed with antiphosphotyrosine antibodies. As shown in Fig. 9, c-fms and an $85-\mathrm{kD}$ protein become tyrosine phosphorylated and associate with Grb2 in CSF-1-treated $s r c^{+}$OCLs. As is also apparent in this figure, the $85-\mathrm{kD}$ protein comigrates with the $85-\mathrm{kD}$ protein that was noted to be phosphorylated in whole cell lysates from $\mathrm{src}^{+}$ OCLs. To address the question more directly of whether the 85-kD Grb2-binding protein was the same as that seen in whole cell lysates, in vitro depletion studies were done using a GST-Grb2 fusion protein. As shown in Fig. 10 (lanes 1 and 3), repetitive binding of CSF-1-treated whole cell lysates to the GST-Grb2 fusion protein depletes the $85-\mathrm{kD}$ phosphoprotein from the lysates. Analysis of the proteins bound to the GSTGrb2 fusion protein (Fig. 10, lane 2) revealed the presence of the $85-\mathrm{kD}$ phosphoprotein. Taken together, these data are consistent with the conclusion that the $85-\mathrm{kD}$ protein that becomes tyrosine phosphorylated after CSF-1 treatment and the $85-\mathrm{kD}$ phosphoprotein that associates with Grb2 in vivo are

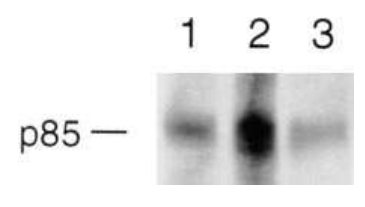

Figure 10. GST-Grb2 binds phosphoprotein 85 ( $p 85)$ in vitro. Phosphotyrosine Western blot of $30 \mu \mathrm{g}$ of whole cell OCL lysate from normal cells, treated for 2 min with CSF-1 (lane 1); eluate of GST-Grb2 after binding to $400 \mu \mathrm{g}$ of the same lysate, demonstrating in vitro binding of phosphoprotein 85 to GST-Grb2 (lane 2); and supernatant from the experiment represented in lane 2 , demonstrating depletion of phosphoprotein 85 from the lysate (lane 3). 

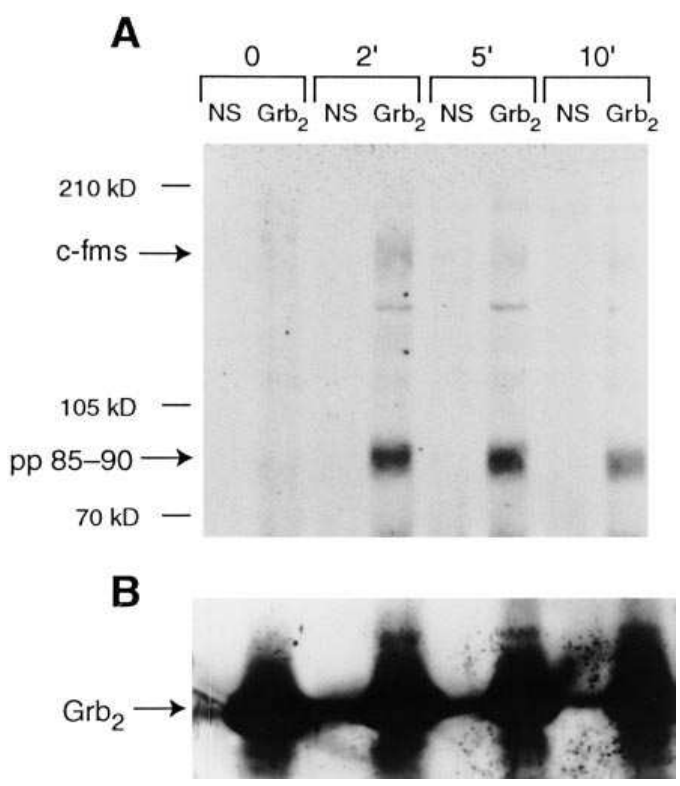

Figure 11. Time course of tyrosine phosphorylation of the $85-90-\mathrm{kD}$ Grb2-binding protein. Whole cell lysates from cells treated with CSF-1 were immunoprecipitated with either normal rabbit serum $(N S)$ or antibody to Grb2 $\left(G r b_{2}\right)$ and analyzed by Western blotting with antibody to phosphotyrosine $(A)$ or Grb2 $(B)$. Grb2 was immunoprecipitated from $500 \mu \mathrm{g}$ of lysate per time point using $1 \mu \mathrm{g}$ of unconjugated antibody. For Western blotting, the Grb2 antibody was used at a final dilution of 1:1,000.

the same molecule. Finally, Fig. 11 illustrates the time course of phosphorylation of the $85-\mathrm{kD}$ Grb2-binding protein and demonstrates that maximal phosphorylation occurs between 2-5 min, which is consistent with the time of maximal phosphorylation for the $85-\mathrm{kD}$ phosphoprotein seen on Western blots of whole cell lysates.

\section{Discussion}

It is clear from the findings in the osteopetrotic op/op mouse that CSF-1 is critical to early osteoclast progenitor proliferation since these animals demonstrate a complete absence of osteoclasts (40-42). However, the focus of this study is on the effects of CSF-1 on the mature osteoclast. The principal findings are as follows: (a) CSF-1 acts directly on mature osteoclasts to induce rapid cytoplasmic spreading in osteoclasts isolated from normal rats and mice; $(b)$ in normal osteoclasts, CSF-1-induced cell spreading is associated with a rapid reorganization of the actin cytoskeleton with apparent disassembly of the attachment ring and polymerization of actin at the spreading edge of the cell; $(c)$ in OCLs, through activation of its receptor, c-fms, CSF-1 induces rapid tyrosine phosphorylation of selected cellular proteins, including c-fms itself, an 8590-kD protein, and c-src; (d) CSF-1 induces a time-dependent increase in c-src kinase activity; $(e)$ in mice with targeted disruption of the $s r c$ gene, there is no well-defined attachment ring, and CSF-1 fails to induce spreading; $(f)$ in OCLs prepared from $s r c^{-}$mice, CSF-1 induces phosphorylation of c-fms but does not lead to normal phosphorylation of an $85-90-\mathrm{kD}$ protein; and $(g)$ the $85-90-\mathrm{kD}$ protein is a Grb2-binding protein.
CSF-1 has been reported to induce membrane ruffling and cell spreading in an SV-40-immortalized murine macrophage cell line. Within 1 min of treatment, actin-rich ruffles are noted in these cells (43). In addition, human peripheral blood monocytes demonstrate chemotaxis in response to CSF-1 (44). Similar observations have been made in isolated rat osteoclasts (14). Specifically, it has been reported that CSF-1 induces rapid cytoplasmic spreading of these cells over a 30-min time course, with the appearance of a cytoplasmic ridge between 2 and $5 \mathrm{~min}$. We corroborated these findings in our preparations of rat osteoclasts and in osteoclasts derived from normal littermates from $s r c^{-}$mice. In these normal cells, we observed that CSF-1 induces rapid reorganization of the actin cytoskeleton, including loss of the actin ring coincident with apparent repolymerization at the spreading edge of the cell. This is consistent with the finding in macrophages of F-actin enrichment at the spreading cell edge after CSF-1 treatment (43).

The response of $\mathrm{src}^{-}$osteoclasts to CSF-1 was in striking contrast to that observed in the normal cells. In these cells, absence of c-src was associated with complete absence of a spreading response to CSF-1. Further, the altered pattern of phalloidin staining both basally and after CSF-1 treatment implicates a role for $s r c$ in regulating the actin cytoskeleton in osteoclasts.

Evidence from experiments in other cell types using v-src temperature-sensitive mutants supports an important role for $s r c$ in cytoskeletal organization. The earliest phenotypic manifestation of $s r c$ activation is membrane ruffling along the cell margins when fibroblasts infected with a temperature-sensitive $\mathrm{v}$-src mutant are shifted from the restrictive to permissive temperature (45). Activation of a temperature-sensitive v-src mutant also leads to association of activated v-src with the detergent-insoluble cytoskeleton, and is accompanied by changes in both actin organization and the distribution of the actin-binding proteins $\alpha$-actinin and vinculin $(46,47)$.

The role of $s r c$ in cytoskeletal regulation has been illuminated further by recent studies in $\mathrm{src}^{-}$fibroblasts. Kaplan et al. (48) reported impaired spreading of fibroblasts isolated from $s r c^{-}$mice when plated on a fibronectin substrate. This defect could be rescued by transfecting the cells with either wild-type $s r c$ or a kinase-deficient mutant $s r c$. However, both the $\mathrm{SH} 2$ and SH3 domains of $s r c$ were required for this effect, since either domain alone did not restore the spreading response. These findings indicate that at least some of the cellular defects in $s r c^{-}$cells can be restored by functions of $s r c$ independent of its kinase activity. Whether this holds true for the defect in the resorptive activity of $s r c^{-}$osteoclasts remains to be determined.

Recent in vivo gain-of-function studies (34) offer some evidence as to the identities of specific substrate proteins that may mediate $s r c$-induced cytoskeletal changes. In these studies, targeted disruption of the gene encoding $c s k$, a negative regulator of $s r c$ family kinases, resulted in the constitutive activation of $s r c$, fyn, and lyn, with consequent embryonic lethality. This phenotype was corrected partially by also deleting $s r c$ $\left(c s k^{-} / s r c^{-}\right)$but not fyn $\left(c s k^{-} / f y n^{-}\right)$. In immortalized cell lines derived from $c s k^{-}$animals, the actin-binding proteins cortactin and tensin were hyperphosphorylated, and abnormalities in the formation of actin stress fibers were observed. The hyperphosphorylation of cortactin was suppressed, and its distribution was normalized in $c s k^{-} / s r c^{-}$cells. Further, the defect in actin organization was partially corrected. The hyperphos- 
phorylation of paxillin and focal adhesion kinase were also partially corrected in $c s k^{-} / s r c^{-}$cells. These data suggest that cortactin, tensin, paxillin, and focal adhesion kinase may participate in src-mediated cytoskeletal changes. The relevance of these findings to our observations in osteoclasts remains uncertain. As noted below, we did not observe phosphorylation of cortactin after treatment of normal OCLs with CSF-1. The effects on phosphorylation of tensin, paxillin, and focal adhesion kinase remain to be explored.

The cell signaling events downstream from activated c-fms that lead to cytoskeletal reorganization have not been studied extensively. However, in a macrophage cell line overexpressing c-fms, CSF-1 treatment has been reported to induce serine phosphorylation of talin, a protein known to be important in regulating the actin cytoskeleton (49). We have not yet examined the effect of CSF-1 on talin phosphorylation in OCLs. Our data do indicate an important role for c-src in inducing these changes. In the absence of $s r c$, the pattern of proteins tyrosine phosphorylated in response to CSF-1 is altered. Most notable is the striking difference in the phosphorylation of an $85-90-k D$ protein after CSF-1 treatment. This protein is phosphorylated intensely in wild-type cells, but either is not phosphorylated at all or is significantly less phosphorylated after the same treatment in $s r c^{-}$cells. Our immunoprecipitation studies indicate that this protein is not STAT $1 \alpha$, STAT 3, STAT 5, the 85-kD subunit of PI-3 kinase, gelsolin, or cortactin (data not shown), but that it does bind Grb2. An 85-90-kD Grb2-binding protein has been reported to become tyrosine phosphorylated in the myeloid progenitor cell line, FDC-P1, after CSF-1 treatment (31). This protein has not been cloned or characterized further, and it is not prominent among the phosphoproteins associating with Grb2 in that cell line. However, a prominently tyrosine-phosphorylated, 85-90-kD Grb2binding protein has been reported in fibroblasts treated with fibroblast growth factor (50-52). Fractionation studies have suggested that this protein is membrane-associated, and that its interaction with Grb2 is mediated via the $\mathrm{SH} 2$ domain of Grb2 (50). In contrast, in preliminary studies, we have found that the $85-\mathrm{kD}$ phosphoprotein in OCLs interacts with the carboxy-terminal SH3 domain of Grb2 (53). Our finding that CSF-1 induces tyrosine phosphorylation of c-cbl in OCLs is consistent with the report of Wang et al. that $c-c b l$ is tyrosine phosphorylated after CSF-1 treatment of the macrophage cell line BAC 1.2F5 (54).

The effects of CSF-1 on c-src kinase activity have not been reported previously in primary cultured cells of any type. In NIH 3 T3 cells engineered to overexpress c-fms, CSF-1 treatment led to a 1.7-fold increase in src kinase activity that was accompanied by an increase in tyrosine phosphorylation of the protein (23). In our study, $5 \mathrm{~min}$ of CSF-1 treatment at room temperature led to a 2.4 -fold increase in kinase activity that corresponded to the time of maximal tyrosine phosphorylation of c-src. Alteration in src kinase activity after activation of c-fms could influence subsequent downstream events that might regulate the cytoskeleton, by such pathways as changing the distribution or phosphorylation state of actin-binding proteins.

In summary, our findings indicate that the ability of CSF-1 to induce cell spreading and the concomitant reorganization of the actin cytoskeleton in osteoclasts are dependent, at least in part, on the normal expression of the cytoplasmic tyrosine kinase c-src. In the absence of c-src, downstream signaling events are altered considerably, and the morphologic spreading re- sponse is absent. The failure to respond to CSF-1 in the absence of c-src does not appear to be due to an inability to activate the receptor, as autophosphorylation of c-fms was observed in $s r c^{-}$OCLs.

\section{Acknowledgments}

This work was supported by National Institutes of Health grants AR39571 (K. Insogna) and AR-42927 (R. Baron), and by grants from the Patrick and Catherine Weldon Donaghue Medical Research Foundation (K. Insogna) and Ariad Pharmaceuticals (R. Baron). A. Grey and M. Sahni are recipients of postdoctoral fellowships from the Health Research Council of New Zealand and the Arthritis Foundation, respectively.

\section{References}

1. Baron, R., J.-H. Ravesloot, L. Neff, M. Chakraborty, D. Chatterjee, A. Lomri, and W. Horne. 1993. Biology of the osteoclast. In Cellular and Molecular Biology of Bone. M. Noda, editor. Springer Publishing Company, New York. 445-495.

2. Roodman, D. 1996. Advances in bone biology: the osteoclast. Endocr. Rev. 17:308-332.

3. Lindsay, R. 1995. Estrogen deficiency. In Osteoporosis: Etiology, Diagnosis and Management. L. Riggs and L. Melton, editors. Raven Press, Ltd., New York. 133-160.

4. Weir, E., K. Insogna, and M. Horowitz. 1989. Osteoblast-like cells secrete granulocyte-macrophage colony stimulating factor in response to parathyroid hormone and lipopolysaccharide. Endocrinology. 124:899-904.

5. Felix, R., P. Elford, C. Stoerckle, M. Cecchini, A. Wetterwald, U. Trechsel, H. Fleisch, and B. Stadler. 1988. Production of hematopoietic growth factors by bone tissue and bone cells in culture. J. Bone Miner. Res. 3:27-36.

6. Keeting, P., L. Rifas, S. Harris, D. Colvard, T. Spelberg, W. Peck, and B.L. Riggs. 1991. Evidence for interleukin-1 $\beta$ production by cultured normal human osteoblast-like cells. J. Bone Miner. Res. 6:827-833.

7. Pfeilschifter, J., C. Chenu, A. Bird, G. Mundy, and D. Roodman. 1989. Interleukin-1 and tumor necrosis factor stimulate the formation of human osteoclast-like cells in vitro. J. Bone Miner. Res. 4:113-118.

8. Horowitz, M., M. Brown, K. Insogna, D. Coleman, M. Centrella, J. Phillips, and E. Weir. 1990. PTHrP and PTH induce the secretion of IL-6 by a clonal osteosarcoma cell line. In Molecular and Cellular Biology of Cytokines. Proceedings of the Second International Workshop on Cytokines. M.D. Powanda, J.J. Oppenheim, M.J. Kluger, and C.A. Dinnarello, editors. Wiley-Liss, Inc., New York. 471-476.

9. Kurihara, N., D. Bertolini, T. Suda, Y. Akiyama, and D. Roodman. 1990 IL-6 stimulates osteoclast-like multinucleated cell formation in long-term human marrow cultures by inducing IL-1 release. J. Immunol. 144:4226-4230.

10. Elias, J., W. Tang, and M. Horowitz. 1995. Cytokine and hormonal stimulation of human osteosarcoma interleukin-11 production. Endocrinology. 136: 489-498.

11. Girasole, G., G. Passeri, R.L. Jilka, and S.C. Manolagas. 1994. Interleukin-11: a new cytokine critical for osteoclast development. J. Clin. Invest. 93: 1516-1524.

12. Kanehisa, J., and J. Heersche. 1988. Osteoclastic bone resorption: in vitro analysis of the rate of resorption and migration of individual osteoclasts. Bone (NY). 9:73-79.

13. Owens, J., and T. Chambers. 1993. Macrophage colony-stimulating factor (M-CSF) induces migration in osteoclasts in vitro. Biochem. Biophys. Res. Commun. 195:1401-1407.

14. Fuller, K., J.M. Owens, C.J. Jagger, A. Wilson, R. Moss, and T.J. Chambers. 1993. Macrophage colony-stimulating factor stimulates survival and chemotactic behavior in isolated osteoclasts. J. Exp. Med. 178:1733-1744.

15. Chiba, S., M. Un-No, K. Lee, J. Deeds, R. Neer, and G. Segre. 1994. In situ localization of mRNA for macrophage colony stimulating factor and its receptor after treatment of rats with parathyroid hormone. J. Bone Miner. Res. 9(Suppl. 1):S312. (Abstr.)

16. Hofstetter, W., A. Wetterwald, M. Cecchini, R. Felix, H. Fleisch, and C. Mueller. 1992. Detection of transcripts for the receptor for macrophage colonystimulating factor, c-fms, in murine osteoclasts. Proc. Natl. Acad. Sci. USA. 89: 9637-9641.

17. Weir, E.C., M.C. Horowitz, R. Baron, M. Centrella, B.M. Kacinski, and K.L. Insogna. 1993. Macrophage colony-stimulating factor release and receptor expression in bone cells. J. Bone Miner. Res. 8:1507-1518.

18. Elford, P.R., R. Felix, M. Cecchini, U. Trechsel, and H. Fleisch. 1987. Murine osteoblast-like cells and the osteogenic cell MC3T3-E1 release macrophage colony-stimulating activity in culture. Calcif. Tissue Int. 41:151-156.

19. Felix, R., H. Fleisch, and P.R. Elford. 1989. Bone-resorbing cytokines 
enhance release of macrophage colony-stimulating activity by the osteoblastic cell MC3T3-E1. Calcif. Tissue Int. 44:356-360.

20. Lee, A.W.-M., and A.W. Nienhuis. 1990. Mechanism of kinase activation in the receptor for colony-stimulating factor 1. Proc. Natl. Acad. Sci. USA. 87:7270-7274.

21. Sengupta, A., W.K. Liu, T.G. Yeung, D.C.Y. Yeung, A.R. Frackelton, Jr., and E.R. Stanley. 1988. Identification and subcellular localization of proteins that are rapidly phosphorylated in tyrosine in response to colony-stimulating factor 1. Proc. Natl. Acad. Sci. USA. 85:8062-8066.

22. Parsons, J.T., and M.J. Weber. 1989. Genetics of src: structure and functional organization of a protein tyrosine kinase. Curr. Top. Microbiol. Immunol. 147:79-126.

23. Courtneidge, S.A., R. Dhand, D. Pilat, G.M. Twamley, M.D. Waterfield, and M.F. Roussel. 1993. Activation of Src family kinases by colony stimulating factor-1, and their association with its receptor. EMBO (Eur. Mol. Biol. Organ.) J. 12:943-950.

24. Alonso, G., M. Koegl, N. Mazurenko, and S.A. Courtneidge. 1995. Sequence requirements for binding of Src family tyrosine kinases to activated growth factor receptors. J. Biol. Chem. 270:9840-9848.

25. Soriano, P., C. Montgomery, R. Gese, and A. Bradley. 1991. Targeted disruption of the $c$-src proto-oncogene leads to osteopetrosis in mice. Cell. 64: 693-702.

26. Lowe, C., T. Yoneda, B.F. Boyce, H. Chen, G.R. Mundy, and P. Soriano. 1993. Osteopetrosis in src-deficient mice is due to an autonomous defect of osteoclasts. Proc. Natl. Acad. Sci. USA. 90:4485-4489.

27. Kato, I., T. Yoneda, E. Izbicka, C. Lee, G. Gutierrez, B. Boyce, P. Soriano, and G.R. Mundy. 1991. Osteoclasts deficient in $c$-src tyrosine kinase fail to resorb bone in vitro and in vivo. J. Bone Miner. Res. 6(Suppl. 1):S197.

28. Boyce, B.F., T. Yoneda, C. Lowe, P. Soriano, and G.R. Mundy. 1992. Requirement of pp60c-src expression for osteoclasts to form ruffled borders and resorb bone in mice. J. Clin. Invest. 90:1622-1627.

29. Horne, W.C., L. Neff, D. Chatterjee, A. Lomri, J.B. Levy, and R. Baron. 1992. Osteoclasts express high levels of $\mathrm{pp} 60^{\mathrm{c}-\mathrm{src}}$ in association with intracellular membranes. J. Cell Biol. 119:1003-1013.

30. Lowenstein, E., R. Daly, A. Batzer, W. Li, B. Margolis, R. Lamers, A. Ullrich, E. Skolnik, D. Bar-Sagi, and J. Schlessinger. 1992. The SH2 and SH3 domain-containing protein GRB2 links receptor tyrosine kinases to ras signaling. Cell. 70:431-442.

31. Lioubin, M., G. Myles, K. Carlberg, D. Bowtell, and L. Rohrschneider. 1994. Shc, Grb2, Sos1, and a 150-kilodalton tyrosine-phosphorylated protein form complexes with fms in hematopoietic cells. Mol. Cell. Biol. 14:5682-5690.

32. Su, Y., M. Chakraborty, M. Nathanson, and R. Baron. 1992. Differential effects of the cAMP and PKC pathways on the response of isolated rat osteoclasts to calcitonin. Endocrinology. 131:1497-1502.

33. Kogan, S., M. Doherty, and J. Gitschier. 1987. An improved method for prenatal diagnosis of genetic diseases by analysis of amplified DNA sequences. Application to hemophilia A. N. Engl. J. Med. 317:985-990.

34. Thomas, S., P. Soriano, and A. Imamoto. 1995. Specific and redundant roles of src and fyn in organizing the cytoskeleton. Nature. 376:267-271.

35. Akatsu, T., T. Tamura, T. Takahashi, N. Udagawa, S. Tanaka, T. Sasaki, A. Yamaguchi, N. Nagata, and T. Suda. 1992. Preparation and characterization of a mouse osteoclast-like multinucleated cell population. J. Bone Miner. Res. 7: 1297-1306.

36. Levy, J., and J. Brugge. 1989. Biological and biochemical properties of the $c$-src ${ }^{+}$gene product overexpressed in chicken embryo fibroblasts. Mol. Cell. Biol. 9:3332-3341.

37. Lassar, A., J. Buskin, D. Lockshon, R. Davis, S. Apone, S. Hauschka, and H. Weintraub. 1989. MyoD is a sequence-specific DNA binding protein re- quiring a region of $m y c$ homology to bind to the muscle creatine kinase enhancer. Cell. 58:823-831.

38. Tanaka, S., M. Amling, L. Neff, A. Peyman, E. Uhlmann, J. Levy, and R. Baron. 1996. c- $\mathrm{Cbl}$ is downstream of $\mathrm{c}-\mathrm{Src}$ in a signalling pathway necessary for bone resorption. Nature. 383:528-531.

39. van der Geer, P., and T. Hunter. 1993. Mutation of Tyr697, a GRB2binding site, and Tyr721, a PI 3-kinase binding site, abrogates signal transduction by the murine CSF-1 receptor expressed in Rat-2 fibroblasts. EMBO (Eur. Mol. Biol. Organ.) J. 12:5161-5172.

40. Yoshida, H., S.I. Hayashi, T. Kunisada, M. Ogawa, S. Nishikawa, H. Okamura, T. Suda, L.D. Shultz, and S.I. Nishikawa. 1990. The murine mutation osteopetrosis is in the coding region of the macrophage colony stimulating factor gene. Nature. 345:442-444.

41. Wiktor-Jedrzejczak, W., A. Bartocci, A.W. Ferrante, Jr., A. AhmedAbsari, K.W. Sell, J.W. Pollard, and E.R. Stanley. 1990. Total absence of colony-stimulating factor 1 in the macrophage-deficient osteopetrotic (op/op) mouse. Proc. Natl. Acad. Sci. USA. 87:4828-4832.

42. Felix, R., M.G. Cecchini, and H. Fleisch. 1990. Macrophage colony-stimulating factor restores in vivo bone resorption in the op/op osteopetrotic mouse. Endocrinology. 127:2592-2594.

43. Boocock, C., G. Jones, E. Stanley, and J. Pollard. 1989. Colony-stimulating factor-1 induces rapid behavioral responses in the mouse macrophage line BAC1.2F5. J. Cell Sci. 93:447-456.

44. Wang, J., J. Griffin, A. Rambaldi, Z.G. Chen, and A. Mantovani. 1988 Induction of monocyte migration by recombinant macrophage colony stimulating factor J. Immunol. 141:575-579.

45. Ambros, V.R., L.B. Chen, and J.M. Buchanan. 1975. Surface ruffles as markers for studies of cell transformation by Rous sarcoma virus. Proc. Natl. Acad. Sci. USA. 72:3144-3148.

46. David-Pfeuty, T., and S.J. Singer. 1980. Altered distribution of the cytoskeletal proteins vinculin and $\alpha$-actinin in cultured fibroblasts transformed by Rous sarcoma virus. Proc. Natl. Acad. Sci. USA. 77:6687-6691.

47. Felice, G.R., P. Eason, M.V. Nermut, and S. Kellie. 1990. pp60v-src association with the cytoskeleton induces actin reorganization without affecting polymerization status. Eur. J. Cell Biol. 52:47-59.

48. Kaplan, K., J. Swedlow, D. Morgan, and H. Varmus. 1995. c-Src enhances the spreading of src $-/$ - fibroblasts on fibronectin by a kinase-independent mechanism. Genes Dev. 7:1505-1517.

49. Meenakshi, T., F. Ross, J. Martin, and S. Teitelbaum. 1993. 1,25-dihydroxyvitamin $\mathrm{D}_{3}$ and macrophage colony-stimulating factor-1 synergistically phosphorylate talin. J. Cell. Biochem. 53:145-155.

50. Klint, P., S. Kanda, and L. Claesson-Welsh. 1995. Shc and a novel 89$\mathrm{kDa}$ component couple to the Grb2-Sos complex in fibroblast growth factor2-stimulated cells. J. Biol. Chem. 270:23337-23344.

51. Mohammadi, M., I. Dikic, A. Sorokin, W. Burgess, M. Jaye, and J Schlessinger. 1996. Identification of six novel autophosphorylation sites on fibroblast growth factor receptor 1 and elucidation of their importance in receptor activation and signal transduction. Mol. Cell. Biol. 16:977-989.

52. Kouhara, H., Y. Hadari, T. Spivak-Kroizman, J. Schilling, D. Bar-Sagi, I. Lax, and J. Schlessinger. 1997. A lipid-anchored Grb2-binding protein that links FGF-receptor activation to the Ras/MAPK signaling pathway. Cell. 89 693-702.

53. Sahni, M., E. DiDomenico, K. Insogna, R. Baron, and J. Levy. 1996. Signaling by CSF-1 in osteoclasts involves tyrosine phosphorylation of a novel p85 and its association with GRB2. J. Bone Miner. Res. 11(Suppl. 1):S145. (Abstr.)

54. Wang, Y., Y.-G. Yeung, W. Langdon, and E. Stanley. 1996. c-Cbl is transiently tyrosine-phosphorylated, ubiquitinated, and membrane-targeted following CSF-1 stimulation of macrophages. J. Biol. Chem. 271:17-20. 